The University of Maine

\title{
DigitalCommons@UMaine
}

Earth Science Faculty Scholarship

Earth Sciences

7-23-1993

\section{Regional Distribution of Monsoon and Desert Dust Signals Recorded in Asian Glaciers}

Cameron P. Wake

Paul Andrew Mayewski

University of Maine, paul.mayewski@maine.edu

Xie Zichu

Wang Ping

Li Zhongquin

Follow this and additional works at: https://digitalcommons.library.umaine.edu/ers_facpub Part of the Climate Commons, Geochemistry Commons, Glaciology Commons, and the Hydrology Commons

\section{Repository Citation}

Wake, Cameron P.; Mayewski, Paul Andrew; Zichu, Xie; Ping, Wang; and Zhongquin, Li, "Regional Distribution of Monsoon and Desert Dust Signals Recorded in Asian Glaciers" (1993). Earth Science Faculty Scholarship. 190.

https://digitalcommons.library.umaine.edu/ers_facpub/190 
GEOPHYSICAL RESEARCH LETTERS, VOL. 20, NO. 14, PAGES 1411-1414, JULY 23, 1993

\title{
REGIONAL DISTRIBUTION OF MONSOON AND DESERT DUST SIGNALS RECORDED IN ASIAN GLACIERS
}

\author{
Cameron P. Wake and Paul A. Mayewski \\ Glacier Research Group, University of New Hampshire \\ Xie Zichu, Wang Ping and Li Zhongqin \\ Lanzhou Institute of Glaciology and Geocryology, China
}

\begin{abstract}
Short-term (6 months to 17 years) glaciochemical records have been collected from glacier basins throughout the mountains of central Asia. The spatial distribution of snow chemistry in central Asia is controlled predominantly by the influx of dust from the arid and semi-arid regions in central Asia. The glaciochemical data suggests that glaciers which are removed from large source areas of mineral aerosol, such as those in the Himalaya, the Karakoram, and the southeastern Tibetan Plateau, are the ones most likely to contain longer-term glaciochemical records which detail annual to decadal variation in the strength of the Asian monsoon and long-range transport of Asian dust.
\end{abstract}

\section{Introduction}

Both marine aerosol transported inland with the Asian monsoon and dust derived from the vast arid and semi-arid regions of central Asia play major roles in geochemical cycles in Asia (e.g., Sequeira and Kelkar, 1978; Galloway et al., 1987; Prospero et al., 1985). Although regional precipitation chemistry investigations have been performed in India and eastern China, little is known concerning the spatial and temporal variability of precipitation chemistry on the Tibetan plateau and bordering mountain areas (Harte, 1983; Wake et al., 1990). Here we report on a suite of short-term (6 months to 17 years) glaciochemical data sets which describe the spatial variation of snow chemistry throughout central Asia. This data base is used to quantify the influence of marine aerosol and Asian dust on the chemical content of snow in the mountains of central Asia, and identify glaciers whose chemical records are sensitive to the annual variability of the Asian monsoon and long-range transport of Asian dust.

\section{Sampling and Analysis}

Over the past several years we have collected high resolution glaciochemical records from Sentik Glacier (site 2 in Figure 1)(Lyons and Mayewski, 1983; Mayewski et al., 1983; 1984), Biafo Glacier (site 3)(Wake et al., 1989), and Glacier No. 1 at the headwaters of the Urumqi River (site 10)(Wake et al., 1992). More recently, snow and ice samples have been collected from Ngozumpa Glacier (site 1), Hispar Glacier (site 3), Xixabangma Peak (site 4), Qiang Yong Glacier (site 5), Mt. Geladaindong (site 6), Meikuang Glacier (site 7), Mustagh Ata (8), and Chongce Ice Cap (site 9). Extreme care was taken at all times during sample collection and handling to assure samples remained uncontaminated. Snow samples were analyzed for anions (chloride, sulfate, and nitrate) and cations (sodium, potassium, calcium, and magnesium) using a Dionex Ion Chromatograph model 2010. Detailed methods appear elsewhere (Wake et al., 1992). We also include snow chemistry data from Dunde Ice Cap (site 11)(Thompson et al., 1990).

\section{Copyright 1993 by the American Geophysical Union.}

Regional Setting

The glaciochemical records discussed here cover a wide geographic area (Figure 1), and can be separated into four distinct regions on the basis of landscape, as defined by Alekseyev et al., (1988), and/or climatic regime as reviewed by Ramage (1971), Barry and Chorley (1982), and Hastenrath (1985):

(i) Ngozumpa Glacier (site 1) lies on the southern slopes of the eastern Himalaya. This region is characterized by mixed forest and small scale agriculture below $4500 \mathrm{~m}$. Precipitation is derived from monsoonal air masses during the summer and from westerly depressions during the winter.

(ii) Sentik Glacier (site 2) and Hispar Glacier (site 3) lie in the western Himalaya and Karakoram, respectively. Moisture derived from westerly air masses throughout the year results is high snow accumulation in this region (Mayewski et al., 1984; Wake, 1989). The western Himalaya and, to a lesser extent the Karakoram, are also influenced by precipitation derived from summertime monsoon circulation. In addition, arid and semi-arid regions, including the Thar Desert (Figure 1), lie to the southwest of the Karakoram and the western Himalaya.

(iii) Xixabangma Peak (site 4), Qiang Yong Glacier (site 5), and Mt. Geladaindong (site 6) fall within the grassland steppes which dominate the southeastern Tibetan Plateau. This region receives most of its precipitation from summer plateau monsoon circulation (Murakami, 1976).

(iv) The northern and western regions of the Tibetan Plateau are characterized by semi-arid and arid regions. Meikuang Glacier (site 7) and the Dunde Ice Cap (site 11) lie adjacent to the Qaidam Basin, and Mustagh Ata (site 8) Chongce Ice Cap (site 9) and Glacier No. 1 (site 10) lie adjacent to the Taklamakan desert. Surface material in the Taklamakan and Thar deserts is typically calcareous (Dregne, 1968; McKee, 1979). Numerous large depressions in the Taklamakan Desert and Qaidam Basin contain extensive salt deposits rich in sodium and chloride (Dregne, 1968; Chen and Bowler, 1986). In addition, dust storms occur frequently in the arid and semi-arid regions of central Asia during the spring (Middleton et al., 1986).

\section{Results}

The major ion content of central Asian snow displays a systematic regional variation (Table 1). Glaciers in the northern and western Tibetan plateau (Figure 1, sites 7 to 11) exhibit geometric mean concentrations of calcium greater than $24 \mu \mathrm{eq} \mathrm{kg}^{-1}$, and of sodium, chloride, and sulfate greater than $2.4 \mu \mathrm{eq} \mathrm{kg}-1$. Glaciers in the southeastern Tibetan Plateau (sites 4,5 , and 6) display calcium levels ranging from 1 to $8 \mu \mathrm{eq} \mathrm{kg}^{-1}$, and sodium, chloride, and sulfate levels ranging from 0.4 to $1.5 \mu \mathrm{eq} \mathrm{kg}-1$. Glaciers in the western Himalaya and Karakoram (sites 2 and 3) show geometric mean calcium concentrations of $7.3 \mu \mathrm{eq} \mathrm{kg}^{-1}$ (site 3 only) and sodium, chloride, and sulfate levels ranging from 0.5 to $2.0 \mu \mathrm{eq} \mathrm{kg}-1$. Ngozumpa Glacier (site 1) on the southern slope of the eastern Himalaya shows concentrations of calcium, sodium, chloride, and sulfate, less than $0.4 \mu \mathrm{eq}$ 

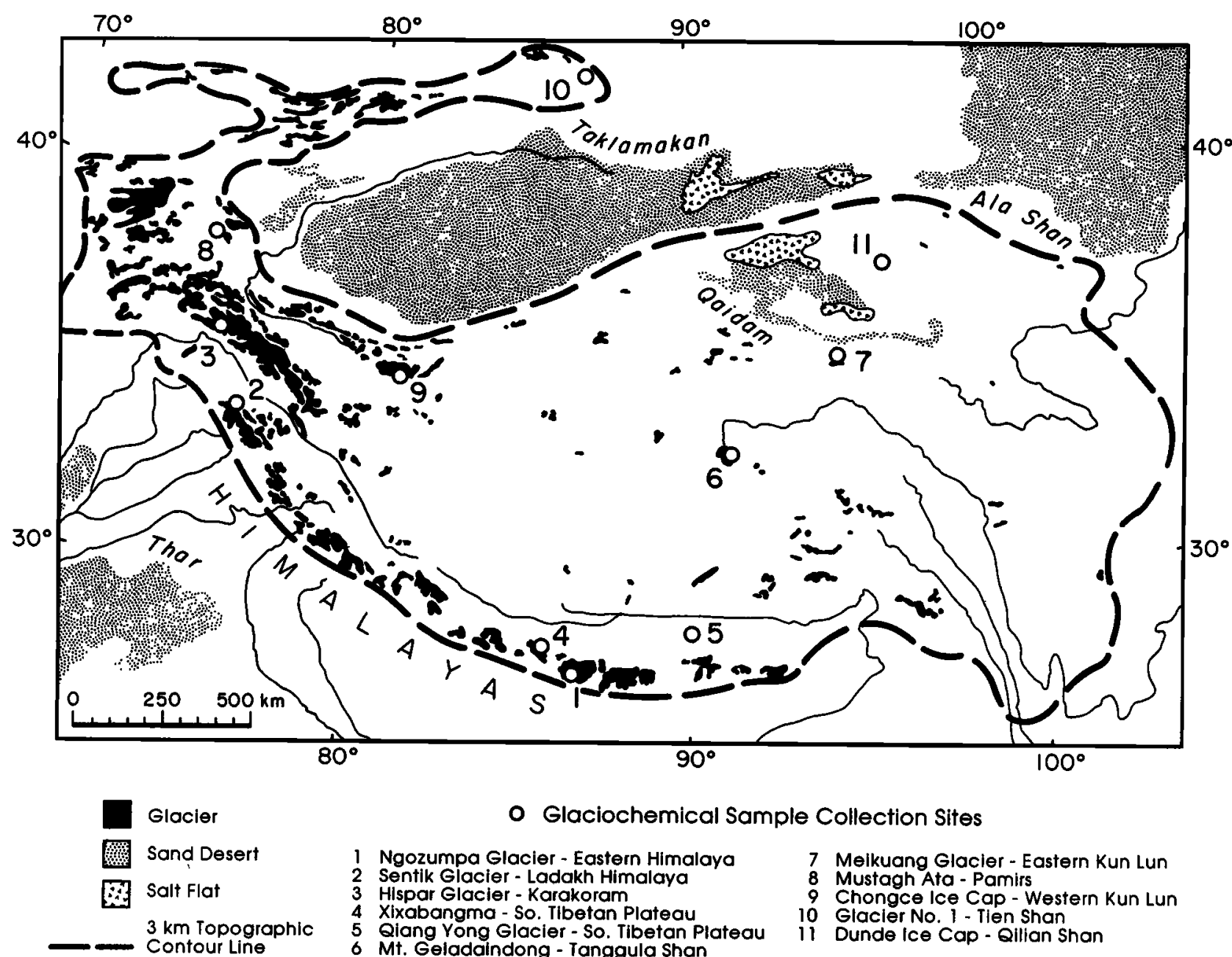

- Glaciochemical Sample Collection Sites

1 Ngozumpa Glacier - Eastern Himalaya 2 Sentik Glacier - Ladakh Himalaya 3 Hispar Glacier - Karakoram

4 Xixabangma - So. Tibetan Plateau

5 Qiang Yong Glacier - So. Tibetan Plateau

6 Mt. Geladaindong - Tanggula Shan

\author{
7 Melkuang Glacier - Eastern Kun Lun \\ 8 Mustagh Ata - Pamirs \\ 9 Chongce Ice Cap - Western Kun Lun \\ 10 Glacler No. 1 - Tien Shan \\ 11 Dunde Ice Cap - Qilian Shan
}

Fig. 1 Location map for glaciochemical collection sites in the mountains of central Asia. The heavy dashed line represents the $3000 \mathrm{~m}$ contour line and outlines the Tibetan Plateau. Landscape and topographic information were derived from a map published by the Royal Geographic Society (1987).

$\mathrm{kg}^{-1}$. In contrast to the chemical species discussed above, nitrate concentrations show less variation in central Asian snow, indicative of a separate and more distant source. However, higher concentrations of nitrate are still associated with higher levels of calcium, sodium, chloride and sulfate.

Measurements of the annual accumulation of major ions is only available for seven sites (Table 2). The annual flux of ions measured in central Asian snow displays similar spatial patterns to those apparent in the ion concentration data. Mustagh Ata (site 8) in the western Tibetan Plateau shows low annual snow accumulation rates but relatively high annual fluxes of calcium, sodium, chloride, and sulfate. Annual ion fluxes in the southeastern Tibetan Plateau (site 4, 5 and 6) are intermediate between the high values at Mustagh Ata and the very low values at Ngozumpa Glacier. Glaciers in the Karakoram and western Himalaya (site 2 and 3 ) show high annual snow accumulation rates and high annual fluxes of calcium, sodium, chloride, sulfate, and nitrate. Ngozumpa Glacier (site 1) displays intermediate value for annual snow accumulation, but very low annual fluxes for all ions.

\section{Discussion}

Snow and ice chemistry at any given site in central Asia is closely associated with proximity to arid and semi-arid regions combined with atmospheric transport pathways. Glaciers in the northern and western Tibetan plateau, which are surrounded by large desert basins (sites 7 through 11), show elevated concentrations of calcium, sodium and chloride as a result of the influx of desert dust. The highest ion burdens were measured at Chongce and Dunde ice caps, which are close to (i.e., $<200 \mathrm{~km}$ ) and downwind of the Taklamakan Desert and Qaidam Basin, respectively. Sodium and chloride signals in the northeastern regions of the Tibetan Plateau which could potentially relate to monsoon precipitation (i.e., peaks of $\approx 0.5 \mu \mathrm{eq} \mathrm{kg}^{-1}$, see below), are effectively masked by sodium and chloride derived from the arid and semi-arid regions in China.

The high levels of sulfate in snow from the northern and western Tibetan Plateau are associated with dust related species (e.g., calcium, sodium, and chloride). While arid and semi-arid regions are potential source regions for sulfate (e.g. Junge and Werby, 1958; Barrie and Hales, 1984), temporal variations in sulfate in central Asian snow do not correlate well with those in calcium, sodium and chloride. Anthropogenic sources of sulfate are recorded in snow from northwest China (Wake et al., 1992) and in snow throughout the former Soviet Union (Belikova et al., 1984). Furthermore, Savoie et al. (1989) suggest that sulfate associated with Sahara dust is derived not from the soil material, but from anthropogenic emissions in Europe and Africa. At present we are uncertain of the relative importance of desert dust and anthropogenic sources with respect to sulfate depostion in central Asia.

Lower concentrations of calcium, sodium, chloride and sulfate in the southeastern Tibetan Plateau (sites 4, 5, and 6) are indicative of a decrease in the mineral aerosol input as a result of longer transport distance from large desert basins in 
Table 1. Summary of geometric mean values of major ion concentrations in central Asian snow

\begin{tabular}{|c|c|c|c|c|c|c|c|c|c|}
\hline $\begin{array}{l}\text { site mountain/ } \\
\text { Fig. } 1 \text { glacier }\end{array}$ & $\begin{array}{c}\text { elev } \\
\text { (m asl) }\end{array}$ & $\begin{array}{l}\text { period of } \\
\text { record* }\end{array}$ & $n$ & $\mathrm{Ca}^{++}$ & $\mathrm{Na}^{+}$ & $\underset{\mathrm{Cl}^{-}}{(\mu \mathrm{eq}} \mathrm{kg}$ & $\mathrm{SO}_{4}=$ & $\mathrm{NO}_{3}^{-}$ & $\mathrm{Na}: \mathrm{Cl} @$ \\
\hline \multicolumn{10}{|c|}{ SOUTH SLOPE - EASTERN HIMALAYA } \\
\hline 1 Ngozumpa & 5700 & $1989-90$ & 30 & 0.40 & 0.31 & 0.33 & 0.24 & 0.11 & $0.98 \pm 0.25$ \\
\hline \multicolumn{10}{|c|}{ WESTERN HIMALAYA \& KaRAKORAM } \\
\hline 2 Sentik** & 4908 & 1963-80 & 99 & na & 1.6 & 1.8 & na & 0.98 & $0.99 \pm 0.57$ \\
\hline 3 Hispar & 5150 & $1985-88$ & 76 & 7.3 & 0.52 & 0.89 & 1.5 & 2.0 & $0.65 \pm 0.25$ \\
\hline \multicolumn{10}{|c|}{ SOUTHEASTERN TIBETAN PLATEaU } \\
\hline 4 Xixabangma & 6140 & $1990-91$ & 31 & 1.2 & 0.37 & 0.54 & 0.45 & 0.55 & $0.97 \pm 0.32$ \\
\hline 5 Qiang Yong & 5850 & $1990-91$ & 17 & 1.2 & 0.38 & 0.49 & 0.36 & 0.62 & $0.85 \pm 0.34$ \\
\hline 6 Geladaindong & g 5950 & $1988-90$ & 40 & 7.8 & 1.4 & 1.3 & 1.4 & 1.5 & $1.1 \pm 0.26$ \\
\hline \multicolumn{10}{|c|}{ NORTHERN \& WESTERN TIBETAN PLATEAU } \\
\hline 7 Meikuang & 5520 & Summr'91 & 12 & 24 & 6.8 & 7.5 & 4.5 & 2.1 & $0.91 \pm 0.06$ \\
\hline 8 Mustagh Ata & 5910 & $1991-92$ & 30 & 31 & 2.4 & 2.5 & 5.6 & 4.0 & $0.97 \pm 0.18$ \\
\hline 9 Chongce 8 & 6327 & $1980-87$ & 77 & 64 & 18 & 17 & 16 & 6.4 & $1.1 \pm 0.38$ \\
\hline 10 Glac No. $1^{* *}$ & 3960 & spring'89 & 27 & 47 & 8.0 & 5.5 & 12 & 3.1 & $2.8 \pm 0.38$ \\
\hline 11 Dunde* & 5325 & $1967-87$ & 10 & 80 & na & 29 & 16 & 3.6 & na \\
\hline
\end{tabular}

geometric means are used as the data from each site approaches a lognormal distribution.

$n$ is the number of samples analyzed; here, na means not available.

* Note that the period of record differs between sites. However, the 1-to-3 fold variation from year-to-year in the geometric mean ion concentrations of snow at sites for which there is more than one year of record (i.e., Sentik, Hispar, Geladaindong, Mustagh Ata) is minimal compared to the much larger variability observed on a spatial scale, suggesting that the data does provide a representative regional perspective.

** Sentik Glacier data from Mayewski et al., 1984; GlacNo1 data from Wake et al., 1992; Dunde Ice Cap data from Thompson et al., 1990; the only published calcium data from Dunde is for circa 1750.

$\$$ The chemical record from a firn/ice core recovered from Chongce Ice Cap (Han et al., 1989) is discontinuous due contamination of the firm samples during transport. Only ion data from the ice sections of the core are reported.

@ The $\mathrm{Na}: \mathrm{Cl}$ ratio is given in $\mu$ eq \pm 1 standard deviation. The ratio from sites 1 through 9 approaches that of sea water (0.86) and halite (1.0). The high ratio for site 10 reflects inputs of $\mathrm{Na}^{+}$rich crustal material (Wake et al., 1992).

western China. The vertical distribution of calcium, sodium, and chloride at site 4,5 , and 6 display strong seasonality. Peaks is all three species occur in the spring/summer layers of the snowpack suggesting that dust raised during the spring dust storm period is transported southward from the Taklamakan Desert and the Qaidam Basin by persistent northwesterly surface winds (Luo and Yanai, 1983; Murakami, 1987). Higher concentrations and annual fluxes of calcium, sodium and chloride at $\mathrm{Mt}$. Geladaindong are consistent with this interpretation, as this glacier lies closer to the mineral aerosol source regions to the north and west. Summertime peaks which are unique to the sodium and chloride time-series, as well as summer snow accumulation, reflect the influx of marine air masses associated with plateau monsoon circulation (Murakami, 1987).

The high annual flux of snow and major ions at Hispar Glacier (site 3), and to a lesser extent at Sentik Glacier (site 2 ), suggests that much of the aerosol and moisture transported with the westerly jet stream is removed as it ascends the southwest margin of the Tibetan Plateau. Sodium and chloride show peaks in spring/summer layers reflecting inputs of marine aerosol from monsoonal air masses and/or inputs of evaporite-rich dust transported from the Thar desert during the springtime dust storm period.

In contrast to sites 2 through 11, snow from Ngozumpa Glacier (site 1) on the southern slopes of the eastern Himalayas displays very low concentrations and annual fluxes of major ions. Ion concentrations and annual fluxes are comparable to those measured in pre-1900 AD snow from Summit Greenland and in snow collected $38 \mathrm{~km}$ upwind of the South Pole (Whitlow et al., 1992). Low calcium levels suggest that high elevation glaciers on the southern slopes of the eastern Himalaya are relatively free from the dominating chemical influence of Asian dust. Sodium and chloride concentrations show peaks in summer layers rising $0.5 \mu \mathrm{eq}$ $\mathrm{kg}^{-1}$ above baseline values $\left(\approx 0.3 \mu \mathrm{eq} \mathrm{kg}^{-1}\right.$ ), reflecting the influence of precipitation derived from monsoonal air masses. The observed chemical patterns are consistent with local (Inoue, 1976; Yasunari, 1976) and synoptic (Luo and Yanai, 1983; Murakami, 1987) meteorology.

Table 2. Annual accumulation of snow and major ions in central Asia

\begin{tabular}{lllll}
\hline $\begin{array}{l}\text { mountain/ } \\
\text { glacier }\end{array}$ & $n$ & $\begin{array}{c}\text { snow } \\
\text { acc.* }\end{array}$ & $\mathrm{Ca}^{++}$ & $\begin{array}{l}\left.\text { (neq } \mathrm{cm}^{-2} \mathrm{yr}^{-1}\right) \\
\mathrm{Na}^{+} \mathrm{Cl}^{-}\end{array} \mathrm{SO}_{4}=\mathrm{NO}_{3}^{-}$ \\
\hline
\end{tabular}

SOUTH SLOPE - EASTERN HIMALAYA

$\begin{array}{lllllllll}\text { Ngozumpa } & 1 & 56 & 26 & 22 & 23 & 13 & 9\end{array}$

WESTERN HMMALAYA \& KARAKORAM

$\begin{array}{lrrrrrrr}\text { Sentik } & 17 & 60 & \text { na } & 152 & 146 & \text { na } & 70 \\ \text { Hispar } & 3 & 130 & 1580 & 273 & 146 & 273 & 390\end{array}$

$\begin{array}{llllllll}\text { SOUTH-EASTERN TIBETAN PLATEAU } \\ \text { Xixabangma } & 1 & \mathbf{6 8} & \mathbf{1 6 9} & \mathbf{3 4} & \mathbf{4 3} & \mathbf{4 5} & \mathbf{4 5} \\ \text { Qiang Yong } & 1 & \mathbf{6 2} & \mathbf{1 3 7} & \mathbf{2 4} & 30 & \mathbf{2 4} & 44 \\ \text { Geladaindong } & 2 & 30 & 794 & \mathbf{7 8} & \mathbf{6 4} & \mathbf{6 2} & \mathbf{7 4}\end{array}$

NORTHERN \& WeStern Tibetan PLATEAU $\begin{array}{llllllll}\text { Mustagh Ata } & 2 & 24 & 1400 & 115 & 108 & 182 & 93\end{array}$

$n$ is the number of years of record; na means not available * snow accumulation is reported in $\mathrm{g} \mathrm{cm}^{-2} \mathrm{yr}^{-1}$ 


\section{Conclusions}

The glaciochemical data set presented here confirms that snow chemistry over the Tibetan plateau is dominated by desert dust derived from the vast arid and semi-arid regions of central Asia, while snow from the southern slopes of the eastern Himalaya is characterized by very low ion burdens representative of relatively clean free tropospheric air. Asian monsoon signals are most clearly recorded at glaciers, such as the southern slopes in the eastern Himalaya, which are well removed from the influence of Asian dust. Glaciers in the western Himalaya, the Karakoram, and the southeastern Tibetan Plateau record combined monsoonal and Asian dust signals, while glaciers in the northern and western regions of the plateau contain records dominated by dust derived from surrounding arid and semi-arid regions. High elevation glaciers in the Himalayas, the Karakoram, and the southeastern Tibetan plateau are therefore most likely to contain longer-term glaciochemical records which reflect regional to hemispheric atmospheric chemistry and climate signals, such as the annual to decadal variation in the strength of the Asian monsoon and the long-range transport of Asian dust.

Acknowledgments. We thank cooperating organizations in India (Aligarh and Kashmir University), Pakistan (Water and Power Development Agency), and Nepal (Tribhuvan University) for assistance in the field, and $S$. Whitlow for assistance in the laboratory. The work in India and China was supported by the National Science Foundation (USA), in Pakistan by Wilfrid Laurier University and the International Development Research Center (Canada), and in Nepal by the General Electric Company Young Employees Nepal 1990 Expedition (England).

\section{References}

Alekseyev, B. A. et. al., Geographic Belts and Zonal Types of Landscapes of the World. Scale 1: 15,000,000. School of Geography, Moscow State University, Moscow. 1988.

Barrie, L. A. and J. M. Hales, The spatial distribution of precipitation acidity and major ion wet deposition in North America during 1980, Tellus 36B, 333-355, 1984.

Barry, R. G. and R. J. Chorley, Atmosphere, Weather \& Climate - 4th ed., Methuen, New York, 1982.

Belikova, T. V., V. N. Vasilenko, I. M. Nazarov, A. N. Pegoev and S. D. Fridman, Characteristics of background sulfate pollution of the snow cover on the territory of the USSR, Meteorologiya $i$ Gidrologiya 9, 47-55, 1984.

Chen, K. and J. M. Bowler, Late Pleistocene evolution of salt lakes in the Qaidam Basin, Qinghai Province, China, Paleogeog., Paleoclimat., Paleoecol. 54, 87-104, 1986.

Dregne, H. E., Surface materials of desert environments, in Deserts of the World, edited by W. G. McGinnies, B. J. Goldman and P. Paylore, 286-377, University of Arizona Press, Tuscon, 1968.

Galloway, J. N., D. Zhou, J. Xiong and G. E. Likens, Acid Rain: China, United States, and a remote area, Science 236, 1559-1562, 1987.

Harte, J., An investigation of acid precipitation in Qinghai Province, China, Atmos. Environ. 17, 403-408, 1983.

Hastenrath, S., Climate and Circulation in the Tropics, D. Reidel, Boston, 1985.

Inoue, J., Climate of Khumbu Himal, Seppyo 38, 66-73, 1976.

Junge, C. E. and R. T. Werby, The concentration of chloride, sodium, potassium, calcium and sulfate in rain water over the United States, J. Meteor. 15, 417-425, 1958.

Luo, $H$. and $M$. Yanai, The large-scale circulation and heat sources over the Tibetan Plateau and surrounding areas during the early summer of 1979. Part I: Precipitation and
Kinematic Analyses, Mon. Weath. Rev. 111, 922-944, 1983.

Lyons, W. B. and P. A. Mayewski, Nitrate plus nitrite concentrations in a Himalayan ice core, Geophys. Res. Lett. 10, 1160-1163, 1983.

McKee, E. D., A Study of Global Sand Seas. Geological Survey Professional Paper 1052; United States Printing Office, Washington, 1979.

Mayewski, P. A., W. B. Lyons W. B. and N. Ahmad, Chemical composition of a high altitude fresh snowfall in the Ladakh Himalayas, Geophys. Res. Lett. 10, 105-108, 1983

Mayewski, P. A., W. B. Lyons, N. Ahmad, G. Smith and M. Pourchet, Interpretation of the chemical and physical time-series retrieved from Sentik Glacier, Ladakh Himalaya, India, J. Glaciol. 30, 66-76, 1984.

Middleton, N. J., A. S. Goudie and G. L. Wells, The frequency and source areas of dust storms. in Aeolian Geomorphology, edited by W. G. Nickling, 237-259. Allen \& Unwin, Boston, 1985.

Murakami, T., Effects of the Tibetan Plateau; in Monsoon Meteorology, edited by C. P. Chang and T. N. Krishnamurti, 235-270, Oxford University Press, New York, 1987.

Prospero, J. M., D. L. Savoie, R. T. Nees, R. A. Duce and J. Merrill, Particulate sulfate and nitrate in the boundary layer over the north Pacific ocean, J. Geophys. Res. 90, $10,586-10,596$.

Ramage, C. S., Monsoon Meteorology, Academic Press, New York, 1971.

Royal Geographic Society, The Mountains of Central Asia, 1:3,000,000 map and Gazeteer, Macmillan, London, 1987.

Savoie, D. L., J. M. Prospero and E. S. Saltzman, Non-seasalt sulfate and nitrate in trade wind aerosols at Barbados: Evidence for long-range transport, J. Geophys. Res 94, 5069-5080, 1989.

Sequeira, R. and D. Kelkar, Geochemical implications of summer monsoonal rainwater composition over India, $J$. App. Meteor. 17, 1390-1396, 1978.

Thompson, L. G., et al., Glacial stage ice-core records from the subtropical Dunde Ice Cap, China, Annal. Glaciol. 14, 288-297.

Wake, C. P., Glaciochemical investigations as a tool for determining the spatial and seasonal variation of snow accumulation in the Central Karakoram, Northern Pakistan, Annal. Glaciol. 13, 279-284, 1989.

Wake, C. P., P. A. Mayewski and M. J. Spencer, A review of central Asian glaciochemical data, Annal. Glaciol. 14, 301-306, 1990.

Wake, C. P., P. A. Mayewski, P. Wang, Q. Yang, J. Han and Z. Xie, Anthropogenic sulfate and Asian dust signals in snow from Tien Shan, northwest China, Annal. Glaciol. 16, 45-52, 1992.

Whitlow S., P. A. Mayewski and J. Dibb, A comparison of major chemical species seasonal concentration and accumulation at the South Pole and Summit, Greenland, Atmos. Environ. 26A, 2045-2054, 1992.

Yasunari, T., Seasonal weather variations in Khumbu Himal, Seppyo 38, 74-83, 1976.

Paul A. Mayewski and Cameron P. Wake, Glacier Research Group, Institute for the Study of Earth, Oceans and Space, University of New Hampshire, Durham, New

Hampshire 03824

Li Zhongqin, Wang Ping and Xie Zichu, Lanzhou Institute of Glaciology and Geocryology, Academia Sinica, Lanzhou 730000, China

Received: March 23, 1993

Accepted: May 5, 1993 